\title{
DETERMINATION OF SHORT-TERM EFFECTS OF WILD FIRE ON SOIL PROPERTIES AND NITROGEN MINERALIZATION IN TURKISH PINE (Pinus brutia Ten.) IN TURKEY (THE CASE OF SARIÇIÇEK SUB-DISTRICT DIRECTORATE)
}

\author{
KUCUK, M. ${ }^{1 *}-$ KAHVECI, U. ${ }^{2}$ \\ ${ }^{1}$ Faculty of Forestry, Artvin Coruh University, Artvin, Turkey \\ ${ }^{2}$ Bolu Forest District Directorate, Bolu, Turkey \\ Corresponding author \\ e-mail: mkck61@artvin.edu.tr; phone: +90-530-886-4528; fax: +90-466-215-1034
}

(Received 24 $4^{\text {th }}$ Aug 2020; accepted $30^{\text {th }}$ Nov 2020)

\begin{abstract}
Forest fires are one of the factors that play an important role in both global warming and nutrient accumulation in soils. The level of these effects varies according to the severity and intensity of the fire. This study was conducted to determine the one-year effects of fire on soil properties and nitrogen mineralization in Turkish Pine stands exposed to low-intensity surface fire that naturally occurred at the Sarıçiçek region the Vezirköprü district of Samsun province in 2014, in Turkey. To this end, six sampling areas were selected from both burned and unburned (control) areas in the sections. Soil samples were taken from a depth of $0-5 \mathrm{~cm}$ and $5-10 \mathrm{~cm}$. Nitrogen mineralization was determined by the land incubation in 3 periods (April-July-October, 2014) on-site holding method. Among soil properties, texture, $\mathrm{pH}$, organic matter, total nitrogen, bulk density and carbon $(\mathrm{C}) /$ nitrogen $(\mathrm{N})$ ratio analyses were assessed. As a conclusion, it was observed that significant differences occurred in soil properties and nitrogen mineralization temporarily. Average nitrogen mineralization at a depth of $0-10 \mathrm{~cm}$ over the one- year period was found to be $23.56 \mathrm{~kg}$ /ha in the burned areas and $25.2 \mathrm{~kg} / \mathrm{ha}$ in the control areas. As a result of the study, it was concluded that the fire was more effective, especially at a depth of $0-5 \mathrm{~cm}$ in regards to changing the soil properties. Nitrogen mineralization at a depth of $0-5 \mathrm{~cm}$ was greater in the burned areas compared to controls. It was determined that especially low-intensity fires were not effective toward the lower depth levels.
\end{abstract}

Keywords: global warming, nutrient accumulation, low-intensity fire, nitrogen mineralization, surface fire

\section{Introduction}

Although forest fires have been regarded as natural disasters for many years, they have been considered to be a part of an ecological system in recent years. Along with the understanding of the dynamics of the ecosystem, natural resource managers can preserve the natural structure of the ecosystem and also ensure its transformation into different structures and compositions by using controlled and purposeful burning applications, which are practical, economical and natural methods, as a management tool (Franklin, 1993; McKenney et al., 1994; Gauthear et al., 1996; James et al., 2018; Quigley et al., 2020).

Indeed, it has been determined in many studies that fires are not just natural events that cause damage. If there were no fires in nature, all forest areas would become monocultures, all kinds of diseases and insect damages would increase and spread due to the excess accumulation of living and dead vegetation, and there would be the excessive accumulation of flammable materials and infertility. Because of all these beneficial aspects of fires, the fire has now become one of the key elements in the management of renewable natural resources (Wright and Bailey, 1982; Alcañiz et al., 2016, 2018). 
Forest fires are an important factor in natural forests and bushes, and they are also useful in the management of afforestation in prescribed burning (Kaye et al., 1999; Johnson et al., 2008; Boerner et al., 2009; Fonseca et al., 2017; Fuentes et al., 2018). A $5.1 \times 10^{8}$ ha forest area is burned mostly due to human activities every year in the world in the global process (Goldammer, 1993; Caldararo, 2002). The direct and indirect effects of forest fires on soil properties in the forest ecosystems have been extensively investigated (Fernandez et al., 1997; Mabuhay et al., 2003; Boerner et al., 2009). Some of these studies explain the effects of fires on soil organic carbon and nitrogen, which determine the soil quality.

Microbial biomass plays an essential role in nitrogen mineralization and carbon sequestration (Hernandes et al., 1997; Jensen et al., 2001; Ilstedt et al., 2003). Nevertheless, these studies do not fully indicate whether the effects of fire on microbial biomass are negative, positive or neutral (Choromanska and DeLuca, 2001; Mabuhay et al., 2003; Liu et al., 2007; Rutigliano et al., 2007; Rodriguez et al., 2009). Most of the studies indicate that there is a strong linear relationship between organic matter and soil respiration and nitrogen mineralization. In other words, the organic matter that is changeable in the soil is used in soil respiration and nitrogen mineralization (Wang et al., 2003; Haynes, 2005; Laik et al., 2009). Fire effectively changes soil respiration and nitrogen mineralization in the long or short term. It also has effects on the physical, chemical, and biological properties of the soil, such as soil moisture, nutrient availability, and microbial activities (DeLuca and Zouhar, 2000; Le Duc and Rothstein, 2007; Hamman et al., 2008). Hamman et al. (2008) indicated that prescribed burning decreased soil moisture in coniferous species, increased soil $\mathrm{pH}$ and significantly changed the nitrogen mineralization.

Some studies have revealed that forest fires are effective in soil respiration and nitrogen mineralization (Fernandez et al., 1997; Choromanska and DeLuca, 2001; Guerrero et al., 2005; Boerner et al., 2006). However, others state that their effects are inconsistent. Namely, while DeLuca and Zouhar (2000) stated that potential mineral nitrogen increased immediately after the fire, Weston and Attiwill (1990) determined that it decreased.

Wang et al. (2012) indicated that organic matter decreased by $20.3 \%$ and nitrogen increased by $13.1 \%$ after the fire compared to control areas. However, they reported that the fire had no significant effect on soil organic matter and total nitrogen. They stated that the highest effect of the fire occurred within the first three months after the fire. In the study, it was also revealed that the forest type and natural fires in natural zones affected total nitrogen and total organic carbon. Accordingly, while organic matter and nitrogen decreased by $25.3 \%$ and $22.7 \%$ in coniferous species, they increased by $28.0 \%$ and $28.7 \%$ in hardwood species. While fire decreased soil respiration by around $13.5 \%$, it decreased nitrogen mineralization by approximately $21.8 \%$. The effect of fire on nitrogen mineralization changed as the depth of soil changed, and there was a decrease by $23.8 \%$ at a depth of 0-5 cm.

The objectives of this study were to determine the $\mathrm{N}$ mineralization potential, soil respiration and some soil properties in Turkish Pine (Pinus brutia Ten.) stands exposed to natural fire in Sarıçiçek region in Vezirköprü district of Samsun province under field conditions, in Turkey. 


$$
\text { - } 8357 \text { - }
$$

\section{Material and Method}

\section{Site description}

Study area is located Vezirköprü, Samsun in the northern Turkey $\left(41^{\circ} 14^{\prime} 21^{\prime \prime} \mathrm{N}-34^{\circ}\right.$ $54^{\prime} 13^{\prime \prime}$ E). This study was conducted in average 60 years old, with $30 \%$ canopy cover Turkish pine (Pinus brutia Ten.) stands exposed to natural fire in the section numbered 28 within the boundaries of Sarıçiçek Forest Sub-District Directorate within Amasya Regional Forest Directorate, Vezirköprü Forest Management Directorate in Turkish Pine stands exposed to natural fire and the control areas next to them (Figure 1). The fire damaged approximately 1 hectare of the forest area. Average slope of the study area was $20-30 \%$ and its aspect was southwest.

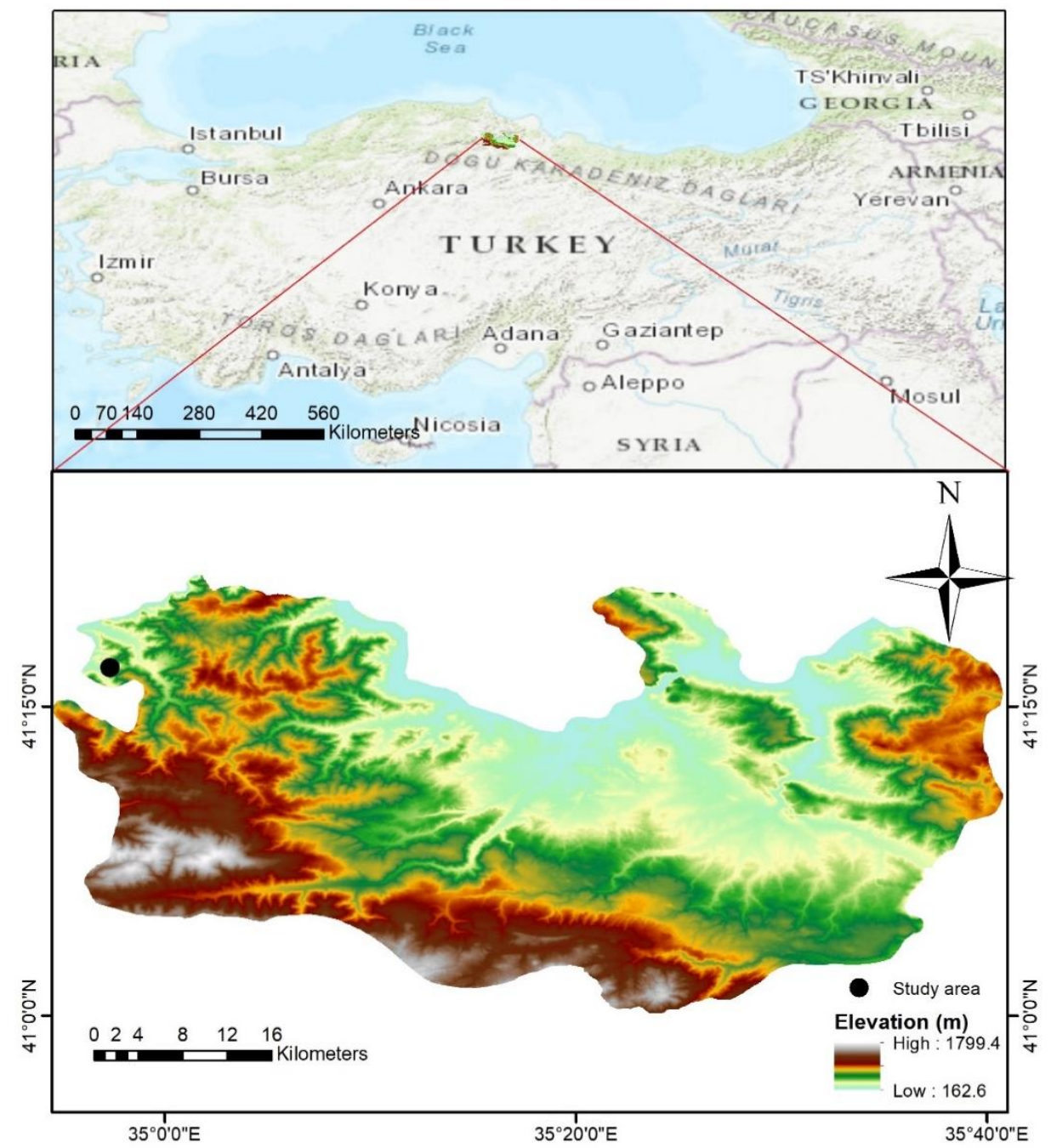

Figure 1. Location (a) (green color) and Digital Elevation Model (ARC-GIS 9.2) (b) of the study area

At the meteorological station where the research area is located, the highest average temperature occurs in July and August by $21.2{ }^{\circ} \mathrm{C}$, the lowest average temperature occurs in January by $0.9^{\circ} \mathrm{C}$, the annual average temperature is $11.5^{\circ} \mathrm{C}$, the lowest average humidity occurs in July by $60.3 \%$, the highest average wind speed occurs in July by 
$2.2 \mathrm{~m} / \mathrm{sec}$, the lowest average precipitation occurs in August by $14 \mathrm{~mm}$, the highest average precipitation occurs in May by $55.1 \mathrm{~mm}$, and the annual precipitation is $415.6 \mathrm{~mm}$.

With regard to geological structure, the Central Black Sea region consists of volcanic rocks such as basalt, andesite and granite. The soil type is generally sandy, clay soil (Anonymous, 2009).

The research area is located in the Euro-Siberian (Euxine) flora area, which is one of Turkey's three major flora regions (Anşin, 1983).

It was determined that the research area was composed of coniferous species (Scotch pine, Corsican pine, and Pinus brutia) and hardwood species (beech and hornbeam). While there are pure beech stands in the area, it was determined that they were also mixed with Scotch pine tree species.

\section{Determination experimental plots method}

The experimental plots were determined by carrying out a preliminary study on Turkish pine areas exposed to natural fire in February 2014 one month after the fire. A total of 12 experimental plots, including six plots from the burned area and six plots from the control areas, were determined (Figure 2). As the size of the experimental plots, $15 \mathrm{~m} * 20 \mathrm{~m}=300 \mathrm{~m}^{2}$ areas were chosen.

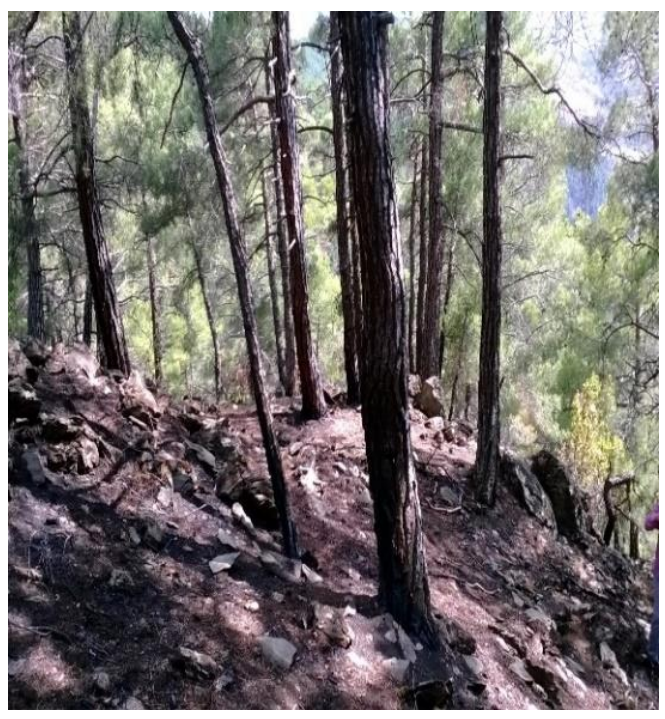

A

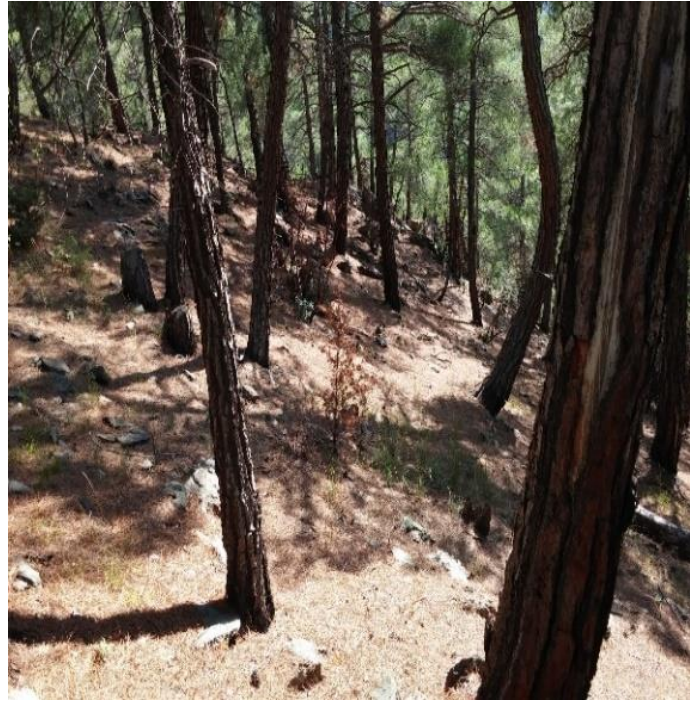

B

Figure 2. Views of burned area $(A)$ and unburned area $(B)$

\section{Taking soil samples}

Twenty-four soil samples ( 6 burned $* 2$ depths $=12,6$ controls $* 2$ depths $=12$, Total 24) were taken from the fire and control areas in every period. Soil sampling was performed in every three months (April 2014, July 2014, and October 2014). Analyses were conducted on a total of 72 soil samples. These soil samples were placed in double plastic bags, labeled and brought to the laboratory environment. 


\section{Net mineralization test}

For nitrogen mineralization, the samples were taken from a depth of $0-5 \mathrm{~cm}$ and $5-10 \mathrm{~cm}$ from each sampling areas. The wet weights were measured by a digital weight meter. The samples were passed through $4 \mathrm{~mm}$ standard steel sieves, and some of them were placed in polyethylene bags, labeled, incubated under field conditions and then buried in the soil for net mineralization measurement. Some of the sieved soil was also labeled and brought to the laboratory to determine the actual mineral nitrogen. Mineralization measurements were conducted in three periods (April 2014 - July 2014, July 2014 - October 2014, and October 2014 - April 2015). Nitrogen mineralization was measured in a total of 432 soil samples, including mineralization and actual (initial) mineralization in field incubation.

\section{Laboratory methods}

The samples taken from the study area to the laboratory environment were dried until they were air-dried. The roots and stones of each sample were removed, labeled and placed in plastic bags. The dried soil samples were crushed in a mortar and sieved using a $2 \mathrm{~mm}$ standard steel sieve. The sieved samples were labeled and prepared for analysis. The texture analysis of the soils was performed based on the Bouyoucos hydrometer method (Gülcur, 1974). The $\mathrm{pH}$ of soil samples was determined by the glass electrode method using an Inolab pH level I pH meter (Gülcur, 1974). The organic matter in the soil was determined by the modified Walkley - Black wet decomposition method (Gülcur, 1974; Kacar, 2009). The Kjeldahl wet digestion method was used for the determination of total nitrogen (Steubing, 1965; Ozturk et al., 1997). The carbon/nitrogen ratio $(\mathrm{C} / \mathrm{N})$ is the ratio of organic carbon and organic nitrogen measured in percent to each other. The samples taken from the field with a soil bulk density cylinder were dried at $105{ }^{\circ} \mathrm{C}$, and the moisture in the soil was removed. After weighing the soil in the bulk, the bulk density was calculated by dividing it by cylinder volume (Gülcur, 1974).

\section{Determination of mineral nitrogen}

In the samples taken from the beginning of April 2014, actual mineral nitrogen and net mineral nitrogen yields were calculated. Mineral nitrogen was identified in a total of 432 soils, 144 soils in each period, at both depth levels. The micro-distillation method was used for the determination of mineral nitrogen in the soil (Bremner and Keeney, 1965; Gerlach, 1973; Güleryüz, 1992). The determination of mineral nitrogen consists of two stages. In the first stage, the amount of ammonium $\left(\mathrm{NH}_{4}{ }^{+}-\mathrm{N}\right)$ in the soil is found, and the amount of nitrate $\left(\mathrm{NO}_{3}{ }^{-} \mathrm{N}\right)$ is determined in the second stage (Öztürk et al., 1997). The net amount of ammonium was calculated by the difference between the ammonium value measured in the samples taken at the end of the incubation period and the ammonium value measured in the samples taken at the beginning of the incubation. This calculation was made for three periods. The annual net $\mathrm{NH}_{4}$ yield was found by summing the ammonium yields obtained over three periods (Eq.l).

$$
\text { Net } \mathrm{NH}_{4}=\text { End of incubation } \mathrm{NH}_{4}-\text { Initial } \mathrm{NH}_{4}
$$

The net amount of nitrate was calculated by the difference between the nitrate value measured in the samples taken at the end of the incubation period and the nitrate value measured in the samples taken at the beginning of the incubation. This calculation was 
made for three periods. The annual net $\mathrm{NO}_{3}$ yield was found by summing the nitrate yields obtained over three periods (Eq.2).

$$
\text { Net } \mathrm{NO}_{3}=\text { End of incubation } \mathrm{NO}_{3}-\text { Initial } \mathrm{NO}_{3}
$$

Net mineral nitrogen yield was calculated by adding the sum of the net ammonium yield and net nitrate yield.

The statistical analysis was performed on the data obtained by using the SPSS 16.0 and Windows statistical software. The analysis of variance was done to determine whether there was a temporal difference in the fire and control areas, and Tukey's test was carried out to determine where the differences were. The difference between the fire and control areas in terms of soil properties was determined by conducting the independent t-test. As a consequence of the tests, letters (such as A, B, AB, a, b) were provided as indicators of significance levels $(\mathrm{P}<0.05)$ and difference in the tables.

\section{Results and Discussion}

\section{Results}

The data obtained by some physical and chemical analyses on the soils are presented in Tables 1 and 2.

Table 1. Temporal change data of some soil properties of the soils at a depth of $0-5 \mathrm{~cm}$

\begin{tabular}{|c|c|c|c|c|c|}
\hline Soil Property & Sample Area & April 2014 & July 2014 & October 2014 & $\begin{array}{c}\text { Significance } \\
\text { level }\end{array}$ \\
\hline Sand & $\begin{array}{c}\text { Control } \\
\text { Fire } \\
\text { Significance level }\end{array}$ & $\begin{array}{c}73.70 \mathrm{Aa} \\
71.02 \mathrm{Aa} \\
0.300\end{array}$ & $\begin{array}{c}72.93 \mathrm{Aa} \\
71.47 \mathrm{Aa} \\
0.472 \\
\end{array}$ & $\begin{array}{c}\text { 77.39Aa } \\
68.68 \mathrm{Ab} \\
\mathbf{0 . 0 0 1} \\
\end{array}$ & $\begin{array}{l}0.207 \\
0.185\end{array}$ \\
\hline Clay & $\begin{array}{c}\text { Control } \\
\text { Fire } \\
\text { Significance level }\end{array}$ & $\begin{array}{c}11.27 \mathrm{Aa} \\
12.74 \mathrm{Aa} \\
0.586\end{array}$ & $\begin{array}{c}6.89 \mathrm{Ba} \\
8.97 \mathrm{Aa} \\
0.182 \\
\end{array}$ & $\begin{array}{c}6.19 \mathrm{Ba} \\
7.49 \mathrm{Aa} \\
0.241 \\
\end{array}$ & $\begin{array}{l}\mathbf{0 . 0 0 0} \\
0.131\end{array}$ \\
\hline Silt & \begin{tabular}{|c|} 
Control \\
Fire \\
Significance level
\end{tabular} & $\begin{array}{c}15.03 \mathrm{Aa} \\
16.24 \mathrm{Aa} \\
0.702\end{array}$ & $\begin{array}{c}20.18 \mathrm{Aa} \\
19.56 \mathrm{ABa} \\
0.786 \\
\end{array}$ & $\begin{array}{c}16.42 \mathrm{Aa} \\
23.82 \mathrm{Bb} \\
0.003\end{array}$ & $\begin{array}{l}0.092 \\
\mathbf{0 . 0 3 7}\end{array}$ \\
\hline $\mathrm{pH}$ & $\mid \begin{array}{c}\text { Control } \\
\text { Fire } \\
\text { Significance level }\end{array}$ & $\begin{array}{c}6.76 \mathrm{Aa} \\
7.03 \mathrm{Aa} \\
0.156\end{array}$ & $\begin{array}{c}7.14 \mathrm{Aa} \\
7.19 \mathrm{Aa} \\
0.806\end{array}$ & $\begin{array}{c}7.17 \mathrm{Aa} \\
7.46 \mathrm{Aa} \\
0.239\end{array}$ & $\begin{array}{l}0.170 \\
0.061\end{array}$ \\
\hline Organic Matter & $\begin{array}{c}\text { Control } \\
\text { Fire } \\
\text { Significance level }\end{array}$ & $\begin{array}{c}7.91 \mathrm{Aa} \\
9.34 \mathrm{Aa} \\
0.143\end{array}$ & $\begin{array}{c}8.01 \mathrm{Aa} \\
8.48 \mathrm{Aa} \\
0.595\end{array}$ & $\begin{array}{c}9.27 \mathrm{Aa} \\
8.33 \mathrm{Aa} \\
0.229\end{array}$ & $\begin{array}{l}0.336 \\
0.263\end{array}$ \\
\hline Total Nitrogen & $\begin{array}{c}\text { Control } \\
\text { Fire } \\
\text { Significance level }\end{array}$ & $\begin{array}{c}0.26 \mathrm{Aa} \\
0.25 \mathrm{Aa} \\
0.744\end{array}$ & $\begin{array}{c}0.26 \mathrm{Aa} \\
0.24 \mathrm{Aa} \\
0.444\end{array}$ & $\begin{array}{c}0.30 \mathrm{Aa} \\
0.23 \mathrm{Ab} \\
\mathbf{0 . 0 0 8}\end{array}$ & $\begin{array}{l}0.297 \\
0.601\end{array}$ \\
\hline $\mathrm{C} / \mathrm{N}$ ratio & $\begin{array}{c}\text { Control } \\
\text { Fire } \\
\text { Significance level }\end{array}$ & $\begin{array}{c}18.0 \mathrm{Aa} \\
22.0 \mathrm{Ab} \\
\mathbf{0 . 0 0 0} \\
\end{array}$ & $\begin{array}{c}18.2 \mathrm{Aa} \\
20.9 \mathrm{Ab} \\
\mathbf{0 . 0 0 7} \\
\end{array}$ & $\begin{array}{c}18.3 \mathrm{Aa} \\
21.0 \mathrm{Ab} \\
\mathbf{0 . 0 0 1} \\
\end{array}$ & $\begin{array}{l}0.880 \\
0.222\end{array}$ \\
\hline Bulk Density & \begin{tabular}{|c|} 
Control \\
Fire \\
Significance level
\end{tabular} & $\begin{array}{c}1.09 \mathrm{Aa} \\
1.06 \mathrm{Aa} \\
0.511\end{array}$ & $\begin{array}{c}0.99 \mathrm{Aa} \\
0.92 \mathrm{Aa} \\
0.136\end{array}$ & $\begin{array}{c}0.96 \mathrm{Aa} \\
0.92 \mathrm{Aa} \\
0.680\end{array}$ & $\begin{array}{l}0.126 \\
0.149\end{array}$ \\
\hline
\end{tabular}


Table 2. Temporal change data of some soil properties of the soils at a depth of $5-10 \mathrm{~cm}$

\begin{tabular}{|c|c|c|c|c|c|}
\hline Soil Property & Sample Area & April 2014 & July 2014 & October 2014 & $\begin{array}{c}\text { Significance } \\
\text { level }\end{array}$ \\
\hline \multirow{3}{*}{ Sand } & Control & $64.5 \mathrm{Aa}$ & $67.3 \mathrm{ABa}$ & $73.8 \mathrm{Ba}$ & 0.023 \\
\hline & Fire & $65.5 \mathrm{Aa}$ & 68.9Aa & 66.4Ab & 0.594 \\
\hline & Significance level & 0.773 & 0.621 & 0.029 & \\
\hline \multirow{3}{*}{ Clay } & Control & $18.5 \mathrm{Aa}$ & $13.5 \mathrm{ABa}$ & $7.8 \mathrm{Ba}$ & 0.001 \\
\hline & Fire & 14.9Aa & $10.2 \mathrm{Aa}$ & $9.5 \mathrm{Aa}$ & 0.053 \\
\hline & Significance level & 0.288 & 0.125 & 0.088 & \\
\hline \multirow{3}{*}{ Silt } & Control & $17.04 \mathrm{Aa}$ & $19.23 \mathrm{Aa}$ & $18.44 \mathrm{Aa}$ & 0.623 \\
\hline & Fire & $19.56 \mathrm{Aa}$ & $20.88 \mathrm{Aa}$ & $24.12 \mathrm{Aa}$ & 0.254 \\
\hline & Significance level & 0.150 & 0.588 & 0.062 & \\
\hline \multirow{3}{*}{$\mathrm{pH}$} & Control & $6.43 \mathrm{Aa}$ & 7.20Aa & 7.30Aa & 0.060 \\
\hline & Fire & $6.57 \mathrm{Aa}$ & $6.90 \mathrm{Aa}$ & 7.48Ba & 0.000 \\
\hline & Significance level & 0.726 & 0.091 & 0.507 & \\
\hline \multirow{3}{*}{ Organic Matter } & Control & 4.31Aa & $5.73 \mathrm{ABa}$ & 7.24Ba & 0.048 \\
\hline & Fire & $6.08 \mathrm{ABb}$ & $4.86 \mathrm{Aa}$ & $6.97 \mathrm{Ba}$ & 0.026 \\
\hline & Significance level & 0.030 & 0.411 & 0.787 & \\
\hline \multirow{3}{*}{ Total Nitrogen } & Control & $0.14 \mathrm{Aa}$ & $0.16 \mathrm{Aa}$ & $0.19 \mathrm{Aa}$ & 0.134 \\
\hline & Fire & $0.16 \mathrm{ABa}$ & $0.14 \mathrm{Aa}$ & $0.18 \mathrm{Ba}$ & 0.019 \\
\hline & Significance level & 0.122 & 0.448 & 0.549 & \\
\hline \multirow{3}{*}{$\mathrm{C} / \mathrm{N}$ ratio } & Control & $18.1 \mathrm{Aa}$ & $21.2 \mathrm{Aa}$ & $21.6 \mathrm{Aa}$ & 0.042 \\
\hline & Fire & $21.6 \mathrm{Ab}$ & 20.6Aa & $22.1 \mathrm{Aa}$ & 0.306 \\
\hline & Significance level & 0.013 & 0.605 & 0.689 & \\
\hline \multirow{3}{*}{ Bulk Density } & Control & $1.12 \mathrm{Aa}$ & $1.21 \mathrm{Aa}$ & $1.15 \mathrm{Aa}$ & 0.640 \\
\hline & Fire & 1.10Aa & $1.15 \mathrm{Aa}$ & $1.14 \mathrm{Aa}$ & 0.703 \\
\hline & Significance level & 0.522 & 0.346 & 0.964 & \\
\hline
\end{tabular}

According to these data, at a depth of $0-5 \mathrm{~cm}$, while soil properties such as sand, nitrogen content and bulk density generally decreased with the fire, properties such as clay, silt, $\mathrm{pH}$, organic matter and $\mathrm{C} / \mathrm{N}$ ratio increased. Along the passage of time over the fire, sand, clay, organic matter, nitrogen, and bulk density decreased. This decrease or increase was not found to be statistically significant, except for the silt in the fire area. The difference in soil properties values between the burned area and unburned area was not generally statistically significant. The increase or decrease in soil properties were at very low levels.

At a depth of $5-10 \mathrm{~cm}$, while soil properties such as sand, silt, $\mathrm{pH}$, and $\mathrm{C} / \mathrm{N}$ ratio generally increased with the fire, properties such as clay, organic matter, nitrogen, and bulk density tended to decrease. The difference in soil properties values between the burned area and unburned area at a depth of 5-10 cm was not statistically significant. The increase or decrease in soil properties was at very low levels. The temporal change in soils in the areas exposed to fire was found to be statistically significant in $\mathrm{pH}$, organic matter, and nitrogen values.

Net nitrogen mineralization values are presented in Table 3. At a depth of $0-5 \mathrm{~cm}$, while the amount of ammonium was lower in the fire areas than control areas, the amount of nitrate was higher. In the mineralization measurements performed in the burned areas, 
while it was revealed that ammonium tended to decrease first and then to increase and finally to decrease compared to the control areas, there was an increase, and then an increase and finally a decrease in nitrate values. The total mineralization value at a depth of 0-5 cm was found to be low in the fire area only in the October 2014-April 2015 mineralization period. The total annual mineralization value was identified to be slightly higher in the fire area. The temporal change in the fire areas was determined to be significant in ammonium and total nitrogen mineralization $(\mathrm{P}<0.05)$. The difference in all mineral nitrogen values between the burned area and unburned area was found to be statistically insignificant $(\mathrm{p}>0.05)$.

Table 3. Mean net nitrogen mineralization values at a depth of $0-5 \mathrm{~cm}$ and $5-10 \mathrm{~cm}$

\begin{tabular}{|c|c|c|c|c|c|c|c|}
\hline & \multirow[b]{2}{*}{ Sample Area } & \multirow[b]{2}{*}{ Depth } & \multicolumn{3}{|c|}{ Measurement Period } & \multirow[b]{2}{*}{$\begin{array}{c}\text { Total } \\
\text { Annual }\end{array}$} & \multirow[b]{2}{*}{$\begin{array}{c}\text { Significance } \\
\text { level }\end{array}$} \\
\hline & & & $\begin{array}{c}\text { April-July } \\
2014\end{array}$ & $\begin{array}{c}\text { July- } \\
\text { October } \\
2014 \\
\end{array}$ & \begin{tabular}{|c|} 
October \\
2014- April \\
2015 \\
\end{tabular} & & \\
\hline \multirow{3}{*}{$\begin{array}{c}\mathrm{NH}_{4} \\
(\mathrm{~kg} / \mathrm{ha})\end{array}$} & Fire & & $1.58 \mathrm{Aa}$ & $1.59 \mathrm{Aa}$ & $2.57 \mathrm{Ba}$ & $5.74 \mathrm{a}$ & 0.008 \\
\hline & Control & U-J cm & $1.64 \mathrm{Aa}$ & $1.53 \mathrm{Aa}$ & $2.7 \mathrm{Ba}$ & $5.87 \mathrm{a}$ & 0.010 \\
\hline & $\begin{array}{c}\text { Significance } \\
\text { level }\end{array}$ & & 0.863 & 0.865 & 0.720 & 0.786 & \\
\hline \multirow{3}{*}{$\begin{array}{c}\mathrm{NO}_{3} \\
(\mathrm{~kg} / \mathrm{ha})\end{array}$} & Fire & 05 & $2.14 \mathrm{Aa}$ & $1.37 \mathrm{Aa}$ & $2.43 \mathrm{Aa}$ & $5.94 \mathrm{a}$ & 0.208 \\
\hline & Control & $0-5 \mathrm{~cm}$ & $1.44 \mathrm{Aa}$ & $1.27 \mathrm{Aa}$ & $2.57 \mathrm{Ba}$ & $5.28 \mathrm{a}$ & 0.012 \\
\hline & $\begin{array}{c}\text { Significance } \\
\text { level }\end{array}$ & & 0.113 & 0.715 & 0.849 & 0.584 & \\
\hline \multirow{3}{*}{$\begin{array}{c}\mathrm{NH}_{4}+\mathrm{NO}_{3} \\
(\mathrm{~kg} / \mathrm{ha})\end{array}$} & Fire & & $3.72 \mathrm{ABa}$ & $2.96 \mathrm{Aa}$ & $5.00 \mathrm{Ba}$ & $11.68 \mathrm{a}$ & 0.032 \\
\hline & Control & $0-5 \mathrm{~cm}$ & $3.08 \mathrm{Aa}$ & $2.80 \mathrm{Aa}$ & $5.27 \mathrm{Ba}$ & $11.15 \mathrm{a}$ & 0.001 \\
\hline & $\begin{array}{c}\text { Significance } \\
\text { level }\end{array}$ & & 0.306 & 0.779 & 0.727 & 0.498 & \\
\hline \multirow{3}{*}{$\begin{array}{c}\mathrm{NH}_{4} \\
(\mathrm{~kg} / \mathrm{ha})\end{array}$} & Fire & $5.10 \mathrm{~cm}$ & $1.50 \mathrm{Aa}$ & $1.49 \mathrm{Aa}$ & $3.2 \mathrm{Ba}$ & $6.19 \mathrm{a}$ & 0.000 \\
\hline & Control & $5-10 \mathrm{~cm}$ & $1.45 \mathrm{Aa}$ & $1.66 \mathrm{Aa}$ & $3.16 \mathrm{Ba}$ & $6.27 \mathrm{a}$ & 0.000 \\
\hline & $\begin{array}{c}\text { Significance } \\
\text { level }\end{array}$ & & 0.915 & 0.448 & 0.893 & 0.578 & \\
\hline \multirow{3}{*}{$\begin{array}{c}\mathrm{NO}_{3} \\
(\mathrm{~kg} / \mathrm{ha})\end{array}$} & Fire & 510 & $1.52 \mathrm{Aa}$ & $1.44 \mathrm{Aa}$ & $2.79 \mathrm{Aa}$ & $5.75 a$ & 0.058 \\
\hline & Control & $5-10 \mathrm{~cm}$ & $2.33 \mathrm{Aa}$ & $1.61 \mathrm{Aa}$ & $3.84 \mathrm{Ba}$ & $7.78 \mathrm{a}$ & 0.000 \\
\hline & $\begin{array}{c}\text { Significance } \\
\text { level }\end{array}$ & & 0.176 & 0.523 & 0.113 & 0.096 & \\
\hline \multirow{3}{*}{$\begin{array}{c}\mathrm{NH}_{4}+\mathrm{NO}_{3} \\
(\mathrm{~kg} / \mathrm{ha})\end{array}$} & Fire & & $3.02 \mathrm{Aa}$ & $2.93 \mathrm{Aa}$ & $5.99 \mathrm{Ba}$ & $11.94 \mathrm{a}$ & 0.003 \\
\hline & & $5-10 \mathrm{~cm}$ & $3.78 \mathrm{Aa}$ & $3.27 \mathrm{Aa}$ & $7.00 \mathrm{Ba}$ & $14.05 \mathrm{a}$ & 0.000 \\
\hline & $\begin{array}{c}\text { Significance } \\
\text { level }\end{array}$ & & 0.389 & 0.430 & 0.201 & 0.128 & \\
\hline
\end{tabular}

At a depth of 5-10 cm, ammonium mineralization was revealed to be low in the fire areas, as at a depth of $0-5 \mathrm{~cm}$. When the temporal change was analyzed, it was determined that the amount of ammonium decreased in the first measurement period, decreased in the second measurement period, and slightly increased in the third measurement period with the fire compared to control areas. Concerning this change in nitrate values, there was a decrease in all three measurement periods. Total mineral nitrogen values were 
determined to be higher in the control area compared to the fire area. The temporal change in the fire areas was found to be statistically significant in ammonium and nitrate values, as at a depth of $0-5 \mathrm{~cm}(\mathrm{P}<0.05)$. The difference between all mineral nitrogen data in the burned and unburned areas was found to be insignificant in all periods $(\mathrm{P}>0.05)$.

The values of nitrogen mineralization per hectare in the burned and unburned areas are presented in Table 4. According to these values, the ratio of nitrate to ammonium was found to be higher than 1 in the fire area at a depth of 0-5 cm. However, it was determined to be low in the control area. At a depth of $5-10 \mathrm{~cm}$, it was greater than 1 in the control area and less than 1 in the fire area. At a depth of $0-10 \mathrm{~cm}$, these ratios were calculated to be 1.08 and 0.98 in the unburned area and burned area, respectively. Nitrification values also revealed similar results. At a depth of $0-10 \mathrm{~cm}$, while annual ammonium mineralization values were $11.93 \mathrm{~kg} / \mathrm{ha}$ and $12.14 \mathrm{~kg} / \mathrm{ha}$ in the burned area and unburned area, respectively, nitrate mineralization values were $11.69 \mathrm{~kg} / \mathrm{ha}$ and $13.06 \mathrm{~kg} / \mathrm{ha}$, respectively. Finally, the total mineralization values were $23.56 \mathrm{~kg} / \mathrm{ha}$ and $25.20 \mathrm{~kg} / \mathrm{ha}$, respectively. Based on these results, it was observed that mineralization values decreased with the fire.

Table 4. Net mineralization and nitrification values and ratios in soils

\begin{tabular}{c|c|c|c|c|c|c}
\hline $\begin{array}{c}\text { Depth } \\
\text { (cm) }\end{array}$ & Parameter & Control & Fire & Parameter & Control & Fire \\
\hline $0-5$ & $\mathrm{NH}_{4}(\mathrm{~kg} / \mathrm{ha})$ & 5.87 & 5.74 & $\mathrm{NH}_{4}(\mathrm{mg} / \mathrm{kg})$ & 12.04 & 12.62 \\
$0-5$ & $\mathrm{NO}_{3}(\mathrm{~kg} / \mathrm{ha})$ & 5.28 & 5.94 & $\mathrm{NO}_{3}(\mathrm{mg} / \mathrm{kg})$ & 11.10 & 12.79 \\
$0-5$ & $\mathrm{NH}_{4}+\mathrm{NO}_{3}(\mathrm{~kg} / \mathrm{ha})$ & 11.15 & 11.68 & $\mathrm{NH}_{4}+\mathrm{NO}_{3}(\mathrm{mg} / \mathrm{kg})$ & 23.14 & 25.41 \\
$0-5$ & $\mathrm{NO}_{3} / \mathrm{NH}_{4}$ & 0.90 & 1.03 & $\mathrm{NO}_{3} / \mathrm{NH}_{4}$ & 0.92 & 1.01 \\
$0-5$ & $\mathrm{NO}_{3} / \mathrm{NH}_{4}+\mathrm{NO}_{3} * 100(\%)$ & 47 & 51 & $\mathrm{NO}_{3} / \mathrm{NH}_{4}+\mathrm{NO}_{3} * 100(\%)$ & 48 & 50 \\
\hline $5-10$ & $\mathrm{NH}_{4}(\mathrm{~kg} / \mathrm{ha})$ & 6.27 & 6.19 & $\mathrm{NH}_{4}(\mathrm{mg} / \mathrm{kg})$ & 11.43 & 11.42 \\
$5-10$ & $\mathrm{NO}_{3}(\mathrm{~kg} / \mathrm{ha})$ & 7.78 & 5.75 & $\mathrm{NO}_{3}(\mathrm{mg} / \mathrm{kg})$ & 14.13 & 10.69 \\
$5-10$ & $\mathrm{NH}_{4}+\mathrm{NO}_{3}(\mathrm{~kg} / \mathrm{ha})$ & 14.05 & 11.94 & $\mathrm{NH}_{4}+\mathrm{NO}_{3}(\mathrm{mg} / \mathrm{kg})$ & 25.56 & 22.11 \\
$5-10$ & $\mathrm{NO}_{3} / \mathrm{NH} 4$ & 1.24 & 0.93 & $\mathrm{NO}_{3} / \mathrm{NH}$ & 1.24 & 0.94 \\
$5-10$ & $\mathrm{NO}_{3} / \mathrm{NH}_{4}+\mathrm{NO}{ }_{3} * 100(\%)$ & 55 & 48 & $\mathrm{NO}_{3} / \mathrm{NH}_{4}+\mathrm{NO}{ }_{3}^{*} 100(\%)$ & 55 & 48 \\
\hline $0-10$ & $\mathrm{NH}_{4}(\mathrm{~kg} / \mathrm{ha})$ & 12.14 & 11.93 & $\mathrm{NH}_{4}(\mathrm{mg} / \mathrm{kg})$ & 23.47 & 24.07 \\
$0-10$ & $\mathrm{NO}_{3}(\mathrm{~kg} / \mathrm{ha})$ & 13.06 & 11.69 & $\mathrm{NO}_{3}(\mathrm{mg} / \mathrm{kg})$ & 25.23 & 23.48 \\
$0-10$ & $\mathrm{NH}_{4}+\mathrm{NO}_{3}(\mathrm{~kg} / \mathrm{ha})$ & 25.20 & 23.56 & $\mathrm{NH}_{4}+\mathrm{NO}_{3}(\mathrm{mg} / \mathrm{kg})$ & 48.7 & 47.55 \\
$0-10$ & $\mathrm{NO}_{3} / \mathrm{NH}$ & 1.08 & 0.98 & $\mathrm{NO}_{3} / \mathrm{NH}$ & 1.07 & 0.98 \\
$0-10$ & $\mathrm{NO}_{3} / \mathrm{NH}_{4}+\mathrm{NO}_{3} * 100(\%)$ & 52 & 50 & $\mathrm{NO}_{3} / \mathrm{NH}_{4}+\mathrm{NO}{ }_{3}^{*} 100(\%)$ & 52 & 49 \\
\hline
\end{tabular}

As a nitrogen mineralization values were calculated in $\mathrm{mg} / \mathrm{kg}$, while the total annual values were $24.07 \mathrm{mg} / \mathrm{kg}$ and $23.47 \mathrm{mg} / \mathrm{kg}$ in the burned area and unburned area, respectively, in ammonium at a depth of $0-10 \mathrm{~cm}$, they were 23.48 and 25.23, respectively, in nitrate and 47.55 and $48.70 \mathrm{mg} / \mathrm{kg}$, respectively, in total mineralization values. In the evaluation of mineralization values in $\mathrm{mg} / \mathrm{kg}$, it was observed that ammonium mineralization increased, and nitrate and total mineralization decreased with the fire at a depth of 0-10 cm. However, it was revealed that all three mineralization components increased with the fire at a depth of 0-5 cm. 


\section{Discussion}

There have been some increases and decreases in the sand, clay and silt values examined in the texture measurements performed in the soil after the fire. However, this alteration was not statistically significant. In many studies, it was concluded that there might be a difference in texture values with the breakdown of soil particles under high temperatures (Iglesias et al., 1997; De Bano et al., 1998, Hubbert et al., 2006; Chief et al., 2012). On the other hand, some researchers stated that there was no significant change in the texture structure of the fire in low-intensity fires (Granged et al., 2012; Scharenbroch et al., 2012). In the presented study, the low fire intensity confirms the findings obtained with a literature study.

Soil $\mathrm{pH}$ values were analyzed; they were revealed to be higher in the topsoil in the fire area compared to the control area. In many studies, it was indicated that the soil $\mathrm{pH}$ value increased after the fire, especially in the topsoil (Certini, 2005; Küçük, 2006; Ekinci, 2006; Scharenbroch et al., 2012; Berber et al., 2015; Muqaddas et al., 2015; Kong et al., 2019). In this study, the effect of fire on $\mathrm{pH}$ was not found to be statistically significant, which can be attributed to the very low intensity of the fire. Some researchers stated that the effect of fire on $\mathrm{pH}$ was statistically insignificant, as in the presented study (Switzer et al., 2012; Meira-Castro et al., 2014; Alcañiz et al., 2016; Valkó et al., 2016; LucasBorja et al., 2020)

Soil organic matter values were examined; it was observed that the effect of the fire was insignificant. The reason for it may be the low severity of the fire because changes in soil properties in low-intensity fires were less. However, in many studies, it is indicated that the fire has a significant effect on the soil organic matter (Johnson and Curtis, 2001; Choromanska and de Luca, 2001; Six et al., 2002; Muqaddas et al., 2015; Alcañiz et al., 2016). On the other hand, in some studies, researchers stated that the effect of forest fire on soil organic matter change was insignificant (Gundale et al., 2005; Lavoie et al., 2010; Valkó et al., 2016). While the soil organic matter values in the fire area were higher in the first six months after the fire compared to the control area, they were found to be lower at later times. When the overall averages were evaluated, the amount of organic matter in the fire area was found to be slightly higher compared to the control area.

The total nitrogen values in the fire area were determined to be close to each other in the first six months after the fire. Then, there was a serious decrease in the fire area. Some researchers stated that, the fire decreased nitrogen in the soil (Dzwonko et al., 2015; Muqaddas et al., 2015; Francos et al., 2019). Based on the statistical evaluation, the effect of the fire on total nitrogen was revealed to be insignificant. However, in many studies, it was concluded that the fire played an increasing role in total nitrogen in the soil (Knoep and Swank, 1993; Johnson and Curtis, 2001; Knoep et al., 2004; Scharenbroch et al., 2012; Alcañiz et al., 2016).

It was observed that the fire generally played an increasing role in the carbon/nitrogen ratio. The effect of the fire on nitrogen and carbon-nitrogen ratio was also found to be statistically significant. In some studies, it was reported that the $\mathrm{C} / \mathrm{N}$ value increased after the fire (Gundale et al., 2005; Scharenbroch et al., 2012), which is considered to be due to the fact that the increase in organic carbon in the soil after the fire led to an increase in the $\mathrm{C} / \mathrm{N}$ ratio. Likewise, in the correlation analysis, the fact that we found a negative correlation between the $\mathrm{C} / \mathrm{N}$ and total nitrogen supported this statement.

The bulk density values at both depths were revealed to be lower in the fire area in comparison with the control area. However, this low value was not statistically significant. It could be said that the low bulk density in the fire area was caused by higher 
organic matter and ash content in the fire areas. High organic matter decreases bulk density. The effect of time on bulk density was also determined to be insignificant both in the fire area and in the control area. In some studies, researchers stated that bulk density decreased after the fire (Brye, 2006; Chief et al., 2012; Mastrolonardo et al., 2015).

Ammonium mineralization showed lower values in the fire area at a depth of $0-5 \mathrm{~cm}$ after the fire compared to the unburned areas, it exhibited higher values at a depth of $5-10 \mathrm{~cm}$. At a depth of $0-10 \mathrm{~cm}$, this value was also found to be higher in the control areas. However, it was revealed that this alteration was not statistically insignificant. Since the measurements were made on a hectare basis, changes, especially in bulk density and soil moisture content, affected these values because this change was found to be more different in the $\mathrm{mg} / \mathrm{kg}$ measurement units of ammonium mineralization. Especially at a depth of $0-5 \mathrm{~cm}$, ammonium mineralization values were determined to be higher in the burned areas compared to the unburned areas. The fact that the fire in the study area was in the form of a low-intensity surface fire also appeared to play a determining role in this effect. The effect of the fire occurred more significantly at a depth of 0-5 cm. The effect of time on mineralization was found to be significant. Changes in soil temperature, soil moisture, soil $\mathrm{pH}$ and soil organic matter, and therefore, changes in the $\mathrm{C} / \mathrm{N}$ ratio over time can be shown as the factors causing it because these variables change the amount of ammonium in the soil. The periodic change of organic matter in the fire area influences mineral ammonium. The removal of litter on the soil surface in the fire areas could affect the net mineral ammonium values in seasonal changes in soil moisture. In general, the net ammonium yield and nitrate yield are high in moist soils and dry soils, respectively (Anggria et al., 2012).

Mineral nitrate yields were identified to be higher in the fire areas at a depth of $0-5 \mathrm{~cm}$ and in the control areas at a depth of $5-10 \mathrm{~cm}$. These measurements were calculated on a $\mathrm{kg} / \mathrm{ha}$ basis. However, this difference was found to be statistically insignificant. The results obtained when the measurements were evaluated on an $\mathrm{mg} / \mathrm{kg}$ basis did not change the outcome of these changes a lot. Nitrate mineralization on an $\mathrm{mg} / \mathrm{kg}$ basis occurred in the fire area at a depth of $0-5 \mathrm{~cm}$ and in the control area at a depth of 5-10 cm. Therefore, the degree of influence of the fire was also limited at a depth of $0-5 \mathrm{~cm}$. In particular, nitrate mineralization is associated with $\mathrm{pH}$ values. Nitrification events in the soil increase as $\mathrm{pH}$ increases. It is indicated by some researchers that the nitrate content increases as pH increases (Robinson, 1963; Black, 1968; Sahrawat, 1982; Lopez and Martin, 1995; Paul and Clark, 1996; Neary et al., 1999; Anggria et al., 2012). In their study, MikitaBarbato et al. (2015) found that the amount of nitrate in the fire areas was higher compared to the control areas. Fernandez-Fernandez et al. (2015) revealed that the mineral nitrate values in the fire area on a $\mathrm{kg}$ basis were lower compared to the control area. As a reason for it, they indicated the high intensity of the fire. Low fire intensity in our areas may not affect microorganism activities too much. The fact that organic matter is easily decomposed by microorganisms and reaches the appropriate $\mathrm{pH}$ environment enables us to find the nitrate yield in the fire areas in this study higher compared to the control areas. There was also a linear relationship between the amount of organic matter in the soil and nitrogen content mineral nitrate yield. High organic matter plays an increasing role in nitrate mineralization. It is considered that the fact that the organic matter in the fire area was found to be high also led to an increase in the amount of mineral nitrate.

The effect of time on total net mineralization data was determined to be significant both in the fire area and in the control area. As a reason for it, it is considered that 
properties such as changes in temperature and precipitation conditions within the periods and changes in microorganism activities and physiological activities of plants explained this difference. It is also considered that different properties such as organic matter, $\mathrm{pH}$ nitrogen, and $\mathrm{C} / \mathrm{N}$ between periods led to this difference. In many studies, it was determined that organic matter, total nitrogen, and $\mathrm{C} / \mathrm{N}$ value were associated with the total net mineralization values. In various studies, it was also concluded that nitrogen mineralization increased after the fire (Kovacic et al., 1986; Kaye and Hart, 1998; Knoepp and Swank, 1993; Hamman et al., 2008). The researchers attributed this increase to the combustion products, evaporation of organic nitrogen from the soil surface, microorganism activities in the soil, and changes in $\mathrm{pH}$, soil temperature, and moisture in the soil (Blair, 1997; Knoepp et al., 2004).

\section{Conclusions}

As a result of this study, the results of one-year period on the soil properties and biological activities of the fire in the region where red pine grows under extreme growing conditions were evaluated. Since the fire severity is low and it is out of the fire season at the time of the fire, the impact of the fire on the soil properties did not emerge at statistically significant levels. In order to reveal the effect of fire on nitrogen mineralization, especially in red pine ecosystems, it can be investigated by experiment fires with different fire intensities and its effects on soil properties. Again, regional differences can be revealed by planning trial fires in the Mediterranean Region and Black Sea Region in the same period. Again, according to the results of this study, considering that the fire increases the soil $\mathrm{pH}$, organic matter and mineralization amounts, it can facilitate rejuvenation activities by making it easier for the seed to reach the soil by going to cover fire studies, especially during abundant seed years.

Prescribed fire practices ensure that nutrients kept in the litter are transferred to the soil, especially in areas with low litter decomposition. In this way, the seed is provided to reach the soil, and germination and sapling development are positively affected in rejuvenation studies. Practitioners can easily achieve this goal by applying low density cover fire applications in such areas. By performing these applications at regular intervals, an increase in the accumulation of substances, which will trigger the fire, can be prevented. In this way, the possibility of a fire is reduced during periods of intense fire risk.

Acknowledgements. This study has been prepared using the data in Unal Kahveci's master thesis. We would like to thank all the staff of Vezirköprü Forest Management Directorate for their support in the realization of this study.

\section{REFERENCES}

[1] Alcañiz, M., Outeiro, L., Francos, M., Farguell, J., Úbeda, X. (2016): Long-term dynamics of soil chemical properties after a prescribed fire in a Mediterranean forest (Montgrí Massif, Catalonia, Spain). - Sci. Total Environ. 572: 1329-1335.

[2] Alcañiz, M., Outeiro, L., Francos, M., Úbeda, X. (2018): Effects of prescribed fires on soil properties: A review. - Science of the Total Environment 613-614: 944-957. 
[3] Anggria, L., Kasno, A., Rochayati, S. (2012): Effect of organic matter on nitrogen mineralization in flooded and dry soil. - Journal of Agricultural and Biological Science 7(8): 586-590.

[4] Anonymous (2009): Management Plan. - Amasya Forest District Directorate, Vezirköprü Forestry Operation Directorate, Sarıçiçek Forest Sub-district directorate.

[5] Anşin, R. (1983): Flora of Turkey and the spread of prime vegetation types in this region. - Karadeniz University Journal 6(2): 318-339.

[6] Bauhus, J., Khanna, P. K., Raison, R. J. (1993): The effect of fire on carbon and nitrogen mineralization and nitrification in an Australian forest soil. - Soil Research 31(5): 621-639.

[7] Berber, A. S., Tavsanoğlu, C., Turgay, O. C. (2015): Effects of surface fire on soil properties in a mixed chestnut-beech-pine forest in Turkey. - Flamma 6(2): 78-80.

[8] Bilmis, T. (2010): Effects of fire on soil properties and root mass dynamics in Edirne-Keşan Korudağ Forest Sub-district directorate fire area. - Master's thesis, Artvin Çoruh University Science Institute.

[9] Black, C. A. (1968): Soil-plant relationships. - John Willey and Sons Inc., New York, London, Sydney.

[10] Blair, J. M. (1997): Fire, N availability, and plant response in grasslands: a test of the transient maxima hypothesis. - Ecology 78(8): 2359-2368.

[11] Boerner, R. E., Waldrop, T. A., Shelburne, V. B. (2006): Wildfire mitigation strategies affect soil enzyme activity and soil organic carbon in loblolly pine (Pinus taeda) forests. Canadian Journal of Forest Research 36(12): 3148-3154.

[12] Boerner, R. E., Huang, J., Hart, S. C. (2009): Impacts of fire and fire surrogate treatments on forest soil properties: a meta-analytical approach. - Ecological Applications 19(2): 338358.

[13] Bremner, J., Keeney, D. R. (1965): Steam distillation methods for determination of ammonium, nitrate and nitrite. - Analytica chimica acta 32: 485-495.

[14] Brye, K. R. (2006): Soil physicochemical changes following 12 years of annual burning in a humidsubtropical tallgrass prairie: a hypothesis. - Acta Oecol. 30: 407-413.

[15] Caldararo, N. (2002): Human ecological intervention and the role of forest fires in human ecology. - Science of the Total Environment 292(3): 141-165.

[16] Certini, G. (2005): Effects of fire on properties of forest soils: a review. - Oecologia 143(1): $1-10$.

[17] Chief, K., Young, M. H., Shafer, D. S. (2012): Changes in soil structure and hydraulic properties in a wooded- shrubland ecosystem following a prescribed fire. - Soil Sci. Soc. Am. J. 76: 1965-1977.

[18] Choromanska, U., DeLuca, T. H. (2001): Prescribed fire alters the impact of wildfire on soil biochemical properties in a ponderosa pine forest. - Soil Science Society of America Journal 65(1): 232-238.

[19] DeBano, L. F., Neary, D. G., Folliott, P. F. (1998): Fire effects on ecosystems. - John Wiley \& Sons.

[20] DeLuca, T. H., Zouhar, K. L. (2000): Effects of selection harvest and prescribed fire on the soil nitrogen status of ponderosa pine forests. - Forest Ecology and Management 138(1-3): 263-271.

[21] Dzwonko, Z., Loster, S., Gawroński, S. (2015): Impact of fire severity on soil properties and the development of tree and shrub species in a Scots pine moist forest site in southern Poland. - Forest Ecology and Management 342: 56-63.

[22] Ekinci, H. (2006): Effect of forest fire on some physical, chemical and biological properties of soil in Çanakkale, Turkey. - International Journal of Agriculture and Biology 8(1): 102106.

[23] Eron, Z. (1977): Heating effects on forest soil physical properties and subsequent seedling growth. - Ph.D. University of Montana. 
[24] Fernández, I., Cabaneiro, A., Carballas, T. (1997): Organic matter changes immediately after a wildfire in an Atlantic forest soil and comparison with laboratory soil heating. - Soil Biology and Biochemistry 29(1): 1-11.

[25] Fernández-Fernández, M., Gómez-Rey, M. X., González-Prieto, S. J. (2015): Effects of fire and three fire-fighting chemicals on main soil properties, plant nutrient content and vegetation growth and cover after 10 years. - Science of the Total Environment 515: 92 100 .

[26] Fonseca, F., de Figueiredo, T., Nogueira, C., Queirós, A. (2017): Effect of prescribed fire on soil properties and soil erosion in a Mediterranean mountain area. - Geoderma 307: 172180.

[27] Francos, M., Stefanuto, E. B., Úbeda, X., Pereira, P. (2019): Long-term impact of prescribed fire on soil chemical properties in a wildland-urban interface. Northeastern Iberian Peninsula. - Science of the Total Environment 689: 305-311.

[28] Franklin, J. F. (1993): The fundamentals of ecosystem management with applications in the Pacific Northwest. - In: Aplet, G. H., Johnson, N., Olson, J. T., Sample, V. A. (eds.) Defining Sustainable Forestry. Island Press, Washington, DC, pp. 127-144.

[29] Fuentes, L., Duguy, B., Nadal-Sala, D. (2018): Short-term effects of spring prescribed burning on the understory vegetation of a Pinus halepensis forest in Northeastern Spain.Sci. Total Environ. 610: 720-731.

[30] Gauthear, S., Leduc, A., Bergeron, Y. (1996): Forest dynamics modelling under a natural fire cycle: a tool to define natural mosaic diversity in forest management. - Environmental Monitoring and Assessment 39: 417-434.

[31] Gerlach, A. (1973): Methodische Untersuchungen zur Bestimmung der Stickstoffnettomineralisation. - Scripta Geobotanica, 5. Goltze, Göttingen.

[32] Goldammer, J. G. (1993): Historical biogeography of fire: tropical and subtropical. - In: Crutzen, P. J., Goldammer, J. G. (eds.) Fire in the Environment: The Ecological, Atmospheric, and Climatic Importance of Vegetation Fires. Wiley, pp. 297-314.

[33] Granged, A. J. P., Zavala, L. M., Jordán, A., Bárcenas-Moreno, G. (2011): Post-fire evolution of soil properties and vegetation cover in a Mediterranean heathland after experimental burning: a 3-year study. - Geoderma 164: 85-94.

[34] Guerrero, C., Mataix-Solera, J., Gómez, I., García-Orenes, F., Jordán, M. M. (2005): Microbial recolonization and chemical changes in a soil heated at different temperatures. International Journal of Wildland Fire 14(4): 385-400.

[35] Gülçur, F. (1974): Physical and Chemical Analysis Methods of Soil. - İ.Ü. Forest Faculty Publications, F.F. Publication No, 201, Kurtuluş Printing House, Istanbul, 225p.

[36] Güleryüz, G. (1992): Studies on Nutrient Circulation and Productivity in Some Plant Communities of the Uludağ Alpine Zone. - PhD Thesis, Bursa Uludağ University, Institute of Science, Bursa.

[37] Gundale, M. J., DeLuca, T. H., Fiedler, C. E., Ramsey, P. W., Harrington, M. G., Gannon, J. E. (2005): Restoration treatments in a Montana ponderosa pine forest: effects on soil physical, chemical and biological properties. - Forest Ecology and Management 213(1-3): 25-38.

[38] Hamman, S. T., Burke, I. C., Knapp, E. E. (2008): Soil nutrients and microbial activity after early and late season prescribed burns in a Sierra Nevada mixed conifer forest. Forest Ecology and Management 256(3): 367-374.

[39] Haynes, R. J. (2005): Labile organic matter fractions as central components of the quality of agricultural soils: an overview. - Advances in agronomy 85: 221-268.

[40] Hernández, T., Garcia, C., Reinhardt, I. (1997): Short-term effect of wildfire on the chemical, biochemical and microbiological properties of Mediterranean pine forest soils. Biology and fertility of soils 25(2): 109-116.

[41] Hubbert, K. P., Preisler, H. K., Wohlgemuth, P. M., Graham, R. C., Narog, M. G. (2006): Prescribed burning effects on soil physical properties and soil water repellency in a steep chaparral watershed, southern California, USA. - Geoderma 130(3-4): 284-298. 
[42] Iglesias, T., Cala, V., Gonzalez, J. (1997): Mineralogical and chemical modifications in soils affected by a forest fire in the Mediterranean area. - Science of the Total Environment 204(1): 89-96.

[43] Ilstedt, U., Giesler, R., Nordgren, A., Malmer, A. (2003): Changes in soil chemical and microbial properties after a wildfire in a tropical rainforest in Sabah, Malaysia. - Soil Biology and Biochemistry 35(8): 1071-1078.

[44] James, J. A., Kern, C. C., Miesel, J. R. (2018): Legacy effects of prescribed fire season and frequency on soil properties in a Pinus resinosa forest in northern Minnesota. - Forest Ecology and Management 47-57: 415-416.

[45] Jensen, M., Michelsen, A., Gashaw, M. (2001): Responses in plant, soil inorganic and microbial nutrient pools to experimental fire, ash and biomass addition in a woodland savanna. - Oecologia 128(1): 85-93.

[46] Johnson, D. W., Curtis, P. S. (2001): Effects of forest management on soil C and N storage: meta-analysis. - Forest ecology and management 140(2-3): 227-238.

[47] Johnson, D. W., Fenn, M. E., Miller, W. W., Hunsaker, C. F. (2008): Fire effects on carbon and nitrogen cycling in forests of the Sierra Nevada. - Developments in Environmental Science 8: 405-423.

[48] Kacar, B. (2009): Soil Analysis. - Nobel Publication No: 1387. Science, 467.

[49] Kaye, J. P., Hart, S. C. (1998): Ecological restoration alters nitrogen transformations in a ponderosa pine-bunchgrass ecosystem. - Ecological Applications 8(4): 1052-1060.

[50] Kaye, J. P., Hart, S. C., Cobb, R. C., Stone, J. E. (1999): Water and nutrient outflow following the ecological restoration of a ponderosa pine-bunchgrass ecosystem. Restoration Ecology 7(3): 252-261.

[51] Knoepp, J. D., Swank, W. T. (1993): Site preparation burning to improve southern Appalachian pine-hardwood stands: nitrogen responses in soil, soil water, and streams. Canadian Journal of Forest Research 23(10): 2263-2270.

[52] Knoepp, J. D., Vose, J. M., Swank, W. T. (2004): Long-term soil responses to site preparation burning in the southern Appalachians. - Forest Science 50(4): 540-550.

[53] Kong, J.-J., Yang, J., Cai, W. H. (2019): Topography controls post-fire changes in soil properties in a Chinese boreal forest. - Science of the Total Environment 651(2): 26622670.

[54] Kovacic, D. A., Swift, D. M., Ellis, J. E., Hakonson, T. E. (1986): Immediate effects of prescribed burning on mineral soil nitrogen in ponderosa pine of New Mexico. - Soil Science 141(1): 71-76.

[55] Kucuk, M. (2006): Effects of fire on soil respiration, root mass and physical and chemical properties of soil in young Corsican pine stands. - Master Thesis. Kafkas University, Institute of Science, Kars.

[56] Laik, R., Kumar, K., Das, D. K., Chaturvedi, O. P. (2009): Labile soil organic matter pools in a calciorthent after 18 years of afforestation by different plantations. - Applied Soil Ecology 42(2): 71-78.

[57] Lavoie, M., Starr, G., Mack, M. C., Martin, T. A., Gholz, H. L. (2010): Effects of a prescribed fire on understory vegetation, carbon pools, and soil nutrients in a longleaf pineslash pine forest in Florida. - Nat. Areas J. 30(1): 82-94.

[58] Le Duc, S. D., Rothstein, D. E. (2007): Initial recovery of soil carbon and nitrogen pools and dynamics following disturbance in jack pine forests: a comparison of wildfire and clearcut harvesting. - Soil Biology and Biochemistry 39(11): 2865-2876.

[59] Liu, W., Xu, W., Han, Y., Wang, C., Wan, S. (2007): Responses of microbial biomass and respiration of soil to topography, burning, and nitrogen fertilization in a temperate steppe. - Biology and fertility of soils 44(2): 259-268.

[60] Lucas-Borja, M. E., Plaza-Álvarez, P. A., Ortega, R., Miralles, I., González-Romero, J., Sagra, J., Moyaa, D., Zema, D. A., de las Heras, J. (2020): Short-term changes in soil functionality after wildfire and straw mulching in a Pinus halepensis M. forest. - Forest Ecology and Management 457: 117700. 


$$
-8370 \text { - }
$$

[61] Mabuhay, J. A., Nakagoshi, N., Horikoshi, T. (2003): Microbial biomass and abundance after forest fire in pine forests in Japan. - Ecological Research 18: 431-44.

[62] Mastrolonardo, G., Rumpel, C., Forte, C., Doerr, S. H., Certini, G. (2015): Abundance and composition of free and aggregate-occluded carbohydrates and lignin in two forest soils as affected by wildfires of different severity. - Geoderma 245: 40-51.

[63] McKenney, D. W. (ed.) (1994): Towards a set of biodiversity indicators for Canadian forests: proceedings of a forest biodiversity indicators. - Workshop held at Sault Ste. Marie, Ontario on November 29-December 1, 1993. Sault Ste. Marie: Canadian Forest Service-Ontario.

[64] Meira-Castro, A., Shakesby, R. A., Espinha Marques, J., Doerr, S., Meixedo, J. P., Teixeira, J., Chaminé, H. I. (2014): Effects of prescribed fire on surface soil in a Pinus pinaster plantation, northern Portugal. - Environ. Earth Sci. 73(6): 3011-3018.

[65] Mikita-Barbato, R. A., Kelly, J. J., Tate, R. L. (2015): Wildfire effects on the properties and microbial community structure of organic horizon soils in the New Jersey Pinelands. Soil Biology and Biochemistry 86: 67-76.

[66] Muqaddas, B., Zhou, X., Lewis, T., Wild, C., Chen, C. (2015): Long-term frequent prescribed fire decreases surface soil carbon and nitrogen pools in wet sclerophyll forest of Southeast Queensland. - Australia. Sci. Total Environ. 536: 39-47.

[67] Neary, D. G., Klopatek, C. C., DeBano, L. F., Ffolliott, P. F. (1999): Fire effects on belowground sustainability: a review and synthesis. - Forest ecology and management 122(1-2): 51-71.

[68] Neyisci, T. (1989): Effects of Prescribed fire on Soil Chemical Properties and Plant Development in Calabrian pine Forest Ecosystems. - Forestry Research Institute Publications Technical Bulletin Series No: 205.

[69] Oswald, B. P., Davenport, D., Neuenschwander, L. F. (1998): Effects of slash pile burning on the physical and chemical soil properties of Vassar soils. - Journal of Sustainable Forestry 8(1): 75-86.

[70] Ozturk, M., Pirdal, M., Ozdemir, F. (1997): Plant Ecology Applications. - Ege University, Faculty of Science Books Series No, 157, Bornova, İzmir.

[71] Pastor-López, A., Martin-Martin, J. (1995): Potential nitrogen losses due to fire from Pinus halepensis stands in the Alicante Province (Southeastern Spain): Mineralomass variability. - In: The Biswell Symposium: Fire issues and solutions in urban interface and wildland ecosystems. Pacific Southwest Research Station, USDA Forest Service, Albany, CA, pp. 179-182.

[72] Paul, E. A., Clark, F. E. (1996): Soil Microbiology, Ecology and Biochemistry. - 2nd Edition, Academic Press, San Diego, California, 340p.

[73] Quigley, K. M., Kolka, R., Sturtevant, B. R., Dickinson, M. B., Kern, C. C., Donner, D. M., Miesel, J. R. (2020): Prescribed burn frequency, vegetation cover, and management legacies influence soil fertility: Implications for restoration of imperiled pine barrens habitat. - Forest Ecology and Management 470-471: 118163.

[74] Robinson, J. B. (1963): Nitrification in a New Zealand grassland soil. - Plant and Soil 19(2): 173-183.

[75] Rodríguez, A., Duran, J., Fernández-Palacios, J. M., Gallardo, A. (2009): Short-term wildfire effects on the spatial pattern and scale of labile organic-N and inorganic-N and $\mathrm{P}$ pools. - Forest Ecology and Management 257(2): 739-746.

[76] Rutigliano, F. A., De Marco, A., D’Ascoli, R., Castaldi, S., Gentile, A., De Santo, A. V. (2007): Impact of fire on fungal abundance and microbial efficiency in $C$ assimilation and mineralisation in a Mediterranean maquis soil. - Biology and Fertility of Soils 44(2): 377381.

[77] Sahrawat, K. L. (1982): Nitrification in some tropical soils. - Plant and soil 65(2): 281286. 
[78] Scharenbroch, B. C., Nix, B., Jacobs, K. A., Bowles, M. L. (2012): Two decades of lowseverity prescribed fire increases soil nutrient availability in a Midwestern, USA oak (Quercus) forest. - Geoderma 183: 80-91.

[79] Six, J., Callewaert, P., Lenders, S., De Gryze, S., Morris, S. J., Gregorich, E. G., Paustian, K. (2002): Measuring and understanding carbon storage in afforested soils by physical fractionation. - Soil science society of America journal 66(6): 1981-1987.

[80] Steubing, L. (1965): Pflanzenökplogisches Praktikum. - Berlin-Hamburg, Parey.

[81] Switzer, J. M., Hope, G. D., Grayston, S. J., Prescott, C. E. (2012): Changes in soil chemical and biological properties after thinning and prescribed fire for ecosystem restoration in a Rocky Mountain Douglas-fir forest. - For. Ecol. Manag. 275: 1-13.

[82] Valkó, O., Deák, B., Magura, T., Török, P., Kelemen, A., Tóth, K., Horváth, R., Nagy, D. D., Debnár, Z., Zsigrai, G., Kapocsi, I., Tóthmérész, B. (2016): Supporting biodiversity by prescribed burning in grasslands - a multi-taxa approach. - Sci. Total Environ. 572: 13771384.

[83] Wang, W. J., Dalal, R. C., Moody, P. W., Smith, C. J. (2003): Relationships of soil respiration to microbial biomass, substrate availability and clay content. - Soil biology and biochemistry 35(2): 273-284.

[84] Wang, Q., Zhong, M., Wang, S. (2012): A meta-analysis on the response of microbial biomass, dissolved organic matter, respiration, and $\mathrm{N}$ mineralization in mineral soil to fire in forest ecosystems. - Forest Ecology and Management 271: 91-97.

[85] Weston, C. J., Attiwill, P. M. (1990): Effects of fire and harvesting on nitrogen transformations and ionic mobility in soils of Eucalyptus regnant forests of south-eastern Australia. - Oecologia 83(1): 20-26.

[86] Wright, H. A., Bailey, A. W. (1982): Fire Ecology: United States and southern Canada. John Wiley and Sons, New York, 501p. 